\title{
France may break ranks over space station
}

Paris. A French government report on space science last week recommended that France proceed independently of the European Space Agency (ESA) and develop a crew rescue vehicle (CRV) for the international space station Alpha in direct cooperation with Russia.

The CRV was dropped from ESA's planned contribution to the space station last month to reduce the plan's overall costs from ECU3.5 billion (US\$4.6 billion) to ECU1.8 billion (see Nature 374, 586; 1995).

ESA's new plans now consist merely of the Columbus Orbiting Facility (COF), which will be built by Germany and Italy, and the Automated Transfer Vehicle (ATV), a relatively low-cost craft that will ferry freight and fuel to the station, and will be built in France.

Last week's report, which was prepared after discussion with aerospace scientists and industrial companies by François Fillon, the minister of research and higher education, recommends that France should now build the CRV with the Russian space agency, RKA.

The craft would differ from the original design in that it would now be based on the existing Russian Soyuz vehicle, upgraded with technology developed in the CRV programme. The new vehicle would be compatible with the launcher Ariane V, as well as with the space station.

But such a scheme would make it more difficult for ESA to find the money for its own space station plans. The agency has so far obtained commitments from member states to cover just ECU1.2 billion of the costs of its scaled-back space station plans. Fillon's report recommends that France should not increase its current minimal contribution, namely 10 per cent of the costs of COF and 25 per cent of the ATV.

Fillon's report, entitled Refinding a LongTerm Vision for Space Science, was submitted last week to Edouard Balladur, the prime minister. Balladur was defeated in a bid for the presidency in the first round of France's elections last Sunday (23 April). But many observers feel that the plan to upgrade Soyuz is likely to win political and budgetary support, irrespective of who is elected president on 7 May.

The proposal comes at a time when France's National Centre for Space Studies (CNES) is already cutting back on its contribution to ESA, diverting the money saved towards either national programmes or bilateral and multilateral collaboration outside the agency. The proportion of CNES's budget allocated to ESA has decreased from more than half to just 40 per cent this year as a result of its withdrawal from elements of ESA's 'optional' programmes, such as those associated with the space station.

French officials say that their disenchant- ment with ESA is due, in particular, to the deadlock caused by the agency's budgetary problems - which have been caused by a prolonged economic recession in member states - and continuing uncertainty over the future of its manned programmes.

Some feel that France, still the largest contributor to ESA's budget, wants to use its muscle as the world's third largest space power to plough its own furrow more effectively. But Aerospatiale, the country's main aerospace manufacturer, argues that this need not mean that France is becoming "less of a good European".

Company officials point out that European aerospace companies already need to work as consortia to be internationally competitive, and that the government wants only to "put industry in a position where it can defend itself in negotiations with other European companies."

But Mark Giget, of the Paris-based space consultancy Euroconsult, argues that Fillon's report, widely seen as reflecting a strong current of opinion in government circles, is "not very European".

Giget argues that the report represents a missed opportunity for France to have proposed the bold and firm commitments that Europe needs if it is to win long-term support for space from its member states. Although it does recommend that ESA produce proposals for both a moon mission and a specific Earth observation programme by 1997, he argues that the details are vague, and focus too much on French interests.

In any case, much of the report could still end up gathering dust on a ministry shelf as a result of the election. Fillon - an active supporter of Balladur - is likely to be removed from the government. Jacques Chirac, the Gaullist candidate widely tipped as the eventual winner, has already promised that, if elected, he will carry out his own review of the French space programme before the meeting of Europe's space ministers in Toulouse in October.

Declan Butler

\section{Concorsi 'corruption' leads to court}

Munich. In the first case of its kind, eight Italian professors have been suspended from their academic duties after being charged with corruption in making academic appointments.

The eight are accused of unfairly appointing their young collaborators (allievi) in preference to better qualified candidates in two national competitions, known as concorsi, to appoint a total of 25 professors in the medical discipline ENT (ear, nose and throat).

All eight, who have been barred from academic activity pending the outcome of a court case, face criminal charges. Allegations of nepotism are associated with at least two of the appointments.

Seven of the accused were among the ten members of the committees appointed by the research ministry to run concorsi in 1988 and 1992. The eighth is accused of making a deal with committee members to ensure the appointment of his son.

The results of concorsi have occasionally been overturned in the past on procedural grounds. But this is the first time that a criminal action has been brought in connection with the system under which a concorso is held every few years by the ministry of universities and research to arrange appointments to fulltime position.

Shortly before the competition takes place, universities throughout Italy must apply to the research minister for new posts in different disciplines. The minister then appoints committees for each discipline, which both run individual concorsi and choose the winners.

Once the winners have been chosen, each is allocated to a university with a vacant position.

Critics of the system complain that appointments too often involve deals between powerful departmental heads, irrespective of whether they sit on the committees, and that the whole procedure lacks both transparency and clear criteria for appointments to academic positions.

So far, attempts by successive research ministers to introduce such measures have failed because of lack of support in parliament, where many members are themselves professors. But last week, Italy's current research minister, Giorgio Salvini, won government approval for a bill which modifies the concorsi rules.

If the bill is approved by parliament, concorso committees in future will be required to select more candidates than the number of positions available. A shortlist of candidates would thus be prepared, from which individual universities could then make appointments.

Salvini wants the bill to be approved rapidly so he can call the next concorso as soon as possible under new rules. The bill has been granted accelerated passage through parliament to facilitate this. It is likely to be approved because it is in line with new rules on the autonomy of universities (see Nature 365, 682; 1993), and neatly sidesteps the thornier issue of criteria for minimum qualifications - a fact that has not gone unnoticed by Italian academics.

Alison Abbott 